that the judiciary has included certain liberties in respect to commercial activity-whether or not they promote ultimate peace and security-among the rights whose claims to protection from interference are absolute; ${ }^{\mathrm{I} I \mathrm{I}}$ and has introduced further obstructions to the control of nationwide economic activities through a geographical conception of "local" matters. ${ }^{{ }^{42}}$ The result of the latter conception has been the notion of "states' rights" which some groups in the United States are now seeking to change by means of a redistribution of state and federal powers.

It seems evident, however, from the fact that widely differing constitutional provisions have been uniformly construed in such a way as to achieve laissez faire-whether on grounds of "states' rights" or "freedom of trade" or "deprivation of 'property" "- that the notion of "states' rights" is only one of the difficulties to be overcome; and that a separation of personal from economic interests is almost a condition precedent to an effective attack on laissez faire. It should be evident that any attempt to control economic matters, by redefinition of states' rights or by any other method, is likely to meet with strong opposition based on the desire for security of personal interests. ${ }^{143}$ Whether this resistance be encountered in the form of opposition to the adoption of the proposal or in the form of judicial misconstruction after it is adopted, the ultimate result is the same.

\title{
SCALING-DOWN OF ARREARAGES ON CUMULATIVE PREFERRED STOCK
}

Ever since cumulative preferred stock came into fashion, common shareholders have been faced with the dismal prospect produced by accumulations of unpaid dividends so large that normal earnings cannot be expected to make up past arrearages for many years. In such situations, unless some settlement can be made with preferred shareholders, the value of the common shares as incomeyielding securities is very small. This problem is most acute at the end of a period of business depression when common shareholders, actuated by a desire to share in the profits of the more hopeful future, seek to effect a reorganization of the capital structure of the corporation so as to reduce or eliminate the prior

${ }^{14}$ See P. 627 supra. ${ }^{142}$ See p. 629 supra.

${ }^{243}$ Thus a successful drive against the proposed child labor amendment proceeded by convincing many farmers that their children would be unable to help on the farm if the amendment were adopted. The Child Labor Amendment, 9 Social Serv. R. ro7 (I935). The possibility of such confusion arises in the ambiguity of the term "labor," which has both economic and personal significations. It can represent (I) a "commodity" which is sold and purchased; or (2) any expenditure of energy in everyday activity. The experience of Australia with $\S 5 \mathrm{I}(\mathrm{x} x \mathrm{xv})$ suggests an alternative to a grant of power over some subject-matter, such as "conditions of labor," "production," etc. If, instead, an amendment should grant power to govern the relations of certain classes of persons, and if the relations chosen to define these classes were economic-e.g., "employers and employees" ar "vendors and purchasers"-the ambiguity of the principal terms might be partially eliminated. 
claims of the preferred and thus make some part of future profits available for dividends on the common. If common shareholders are willing to give the preferred new securities of sufficient value to compensate them for the relinquishment of their "contractual" rights, such an adjustment can equitably be made. . But, of course, the common is anxious not to dilute its holdings any more than is necessary, and most preferred shareholders can be induced to accept a plan which falls short of full compensation. Difficulties, however, arise when a dissenting minority attacks recapitalization as impairing rights guaranteed by their contract with the corporation. It is the purpose of this note to discuss the devices by which accumulations can be scaled down, the justification for such scaling down, the protection that has been accorded to preferred stockholders, and the means by which more effective protection may be granted.

I

\section{A. CHARTER AMENDMENT}

Since the rights of the shareholder are largely defined in the charter, ${ }^{2}$ the most obvious means by which to modify these rights is by amendment of the charter. Two types of amendment have been adopted with a view to a reduction of accumulations; these may be called the direct and the indirect methods. ${ }^{3}$ The direct method utilizes an amendment which frankly cancels the accumulations. 4 But all courts have refused to sanction such amendments because past

I For a discussion of the proper valuation of new securities, see Nichols, A Rationale of Corporate Reorganizations (1936).

${ }_{2}^{2}$ See Burk v. Ottawa Gas \& Electric Co., 87 Kan. 6, I23 Pac. 857 (IgI2); Page v. Whittenton Mfg. Co., 211 Mass. 424, 97 N.E. 1006 (I9I2); Spear v. Rockland-Rockport Lime Co., Ir 3 Me. 285, 93 Atl. 754 (I9I5).

${ }^{3}$ See 46 Yale L.J. 985,993 (I937).

4 In October, I936, Federal Water Service Corporation, a Delaware corporation doing business in New York, had a deficit of $\$ \mathrm{r}, 233,875.50$. There were outstanding I 59,269 shares of preferred stock and 568,775 of Class $A$ stock. The preferred was divided into $\$ 4, \$ 6, \$ 6.50$, and $\$ 7$ preferred. Dividend accumulations ranged from $\$ 33.25$ on the $\$ 7$ preferred to $\$ 9.67$ on the Class A. A proposed charter amendment offered to exchange for each share of $\$ 4$ preferred, four shares of a new Class A stock; for the $\$ 6$ preferred, six shares; for the $\$ 6.50$, six and onehalf; for the $\$ 7$, seven shares; and for the old Class $A$, one-half share of new Class A. Class $B$ (common) shareholders could purchase new Class $A$ for $\$ r 7$ per share. The Class A stock was entitled to all future earnings of the corporation except that after $\$ 2$ per share had been paid to the Class $\mathrm{A}$, the $\mathrm{B}$ stock was to receive dividends not to exceed Ic per share before any further dividends were paid to Class $A$. In the event of dissolution, the Class $A$ was entitled to all the assets of the corporation except that after $\$ 20$ per share was distributed to Class $A$, Class $B$ was to receive an amount not to exceed Ic per share before any further distribution to Class A. Voting control was to be in Class A. It is clear that the Class B shareholders relinquish all but a nominal interest in the corporation. However, the A group retains approximately a one-fifth interest in the corporation, considerably more than it appears to have on the basis of the existing priorities. This is not a "voluntary" plan, but proposal to substitute the new stock for the old by direct charter amendment requiring the exchange of shares. The plan was set forth in a letter to the stockholders, signed by the president and dated October 23, r936. It was abandoned after the decision in Keller v. Wilson, rgo Atl. II5 (Del. I936), discussed infra p. 648. N.Y. Times, Nov. 12, r936, p. 40. 
accumulations are said to be "vested rights" which cannot be taken away by charter amendment.s Courts, however, have not extended the same protection to the right to future accumulations and have sustained amendments wiping them out. ${ }^{6}$ The conventional justification for this distinction has been that the right to dividends that have matured is "vested" since the right to accumulations, past or future, is by contract given a prior claim to future earnings, and since in either case it is designed to protect the preferred shareholder against long periods of passed dividends, the distinction is hardly justified by resort to the question-begging vested rights terminology. ${ }^{8}$ But the fact that the distinction has been drawn suggests the possibility that some courts may prohibit scaling-down of past accumulations when there is a surplus, but may permit the scaling-down when there is no surplus; a surplus, making payment possible, makes the rights seem more substantial and more "vested." Although no court has adopted this analysis, two New Jersey cases indicate that scaling down of past accumulations will more readily be permitted when there is no surplus. 9

It appeared for a time that the I922 amendment to $\S 26$ of the Delaware Corporation $\mathrm{Law}^{\mathrm{IO}}$ would be construed as changing the rule of the Morris case ${ }^{\mathrm{II}}$ to permit direct scaling down. The pertinent part of the amended statute reads: "Any corporation... may amend its charter ... by increasing or decreasing its authorized capital stock or reclassifying the same, by changing the number, par value, designations, preferences, or other special rights of the shares ... or by making any other change or alteration which may be desired." ${ }_{\mathrm{I2}}$ In Harr v. Pioneer Mechanical Corp., the federal court, in upholding an amendment creating new prior preference stock, spoke as though this statute specifically included accumulations among the rights which could be changed by

$s$ Morris v. American Public Utilities Co., I4 Del. Ch. 136, I22 Atl. 696 (1923); Lonsdale Securities Corp. v. International Mercantile Marine Corp., Ior N.J.Eq. 554, I39 Atl. 50 (1927); Keller v. Wilson, 190 Atl. Ir5 (Del. 1936). This is not to say that such plans have not gone into effect without court action.

${ }^{6}$ Yoakum v. Providence Biltmore Hotel Co., 34 F. (2d) 533 (D.C. R.I. I929); ff. Keller v. Wilson, Igo Atl. Ir5 (Del. 1936).

7 See note 6 supra. See also Lonsdale Securities Corp. v. Int. Mercantile Marine Co., IOI N.J. Eq. 554, I39 Atl. 50 (1927).

${ }^{8}$ That there is at best a hazy distinction between the various amendments held to be and those held not to be violative of vested rights is indicated by the comparison of cases in Curran, Minority Stockholders and the Amendment of Corporate Charters, 32 Mich. L. Rev. 743 (1934). See also 4 Univ. Chi. L. Rev. I39 (I936).

- Cf. Windhurst v. Central Leather Co., Ior N.J. Eq. 543, 138 Atl. 772 (I927) (merger effecting a scaling-down of accumulations was permitted on the ground of laches) with Colgate v. U.S. Leather Co., 75 N.J. Eq. 229, 72 Atl. 126 (1909) (such merger, in the presence of a corporate surplus, was enjoined).

ro Del. Rev. Code 1935, \& 2058.

II I4 Del. Ch. 136, 122 Atl. 696 (1923). $\quad$ s2 See note 6 supra. 
amendment. ${ }^{\mathrm{r3}}$ And in Keller v. Wilson, ${ }^{\mathrm{I} 4}$ the chancellor held that the statute not only permitted direct scaling down of accumulations but could be applied to stock issued before the statute was amended through the operation of the reserved power clause. But the Delaware Superior Court declared that the right to accumulations was a vested right which could not be destroyed by the corporation under the authority of a statute passed subsequent to the issuance of the securities. It went on to announce that the amended $\$ 26$ did not authorize the modification of the right to accumulations which is a vested right, i.e., something more than a special right. ${ }^{x 5}$

The indirect method is to create a new class of stock prior to the old preferred and the accumulations thereon. The new stock is offered in exchange for the old stock and all accumulations. A little junior stock may be thrown in for good measure. ${ }^{x}$ Amendments accomplishing this have been held to alter only "preferences" and not "vested rights";I7 they have been upheld by several courts..$^{18}$ This practice scales down old accumulations unless the shareholders who refuse to exchange their stock are granted as great a share in future profits as they would have received had the amendment not been passed. ${ }^{x 9}$ In the recent case of In re Duer ${ }^{20}$ such protection was refused. Since no statute has been construed to permit direct scaling down and since the propriety of indirect scaling down is a problem of statutory construction, it is difficult to see why dissenters should not be protected from the devastating effect of new prior preference stock.

\section{B. MERGER, CONSOLIDATION, AND SALE OF CORPORATE ASSETS}

A method analogous to indirect scaling down by amendment is the transfer of the enterprise to a different corporation ${ }^{2 x}$ or combination with a different

${ }^{\mathrm{x}} 65$ F. (2d) 332, 335 (C.C.A. 2d 1933), cert. denied, $29 \circ$ U.S. 673 (1933).

34 x80 Atl. 584 (Del. Ch. 1935); 36 Col.L. Rev. 674 (I936); 3 Univ. Chi. L. Rev. 327 (1936).

${ }^{55}$ I9O Atl. 155, IIg (Del. 1936).

${ }^{16}$ See, for example, the $x_{93} 6$ plan of the Goodyear Tire and Rubber Co.

${ }^{17}$ Harr v. Pioneer Mechanical Corp., 65 F. (2d) 332 (C.C.A. 2d r933), cert. denied, 290 U.S. 673 (1933); $c f$. Morris v. American Public Utilities Co., I4 Del. Ch. I36, I22 Atl. 696 (I923).

${ }^{18}$ See cases cited in note $\mathrm{r}_{3}$ supra; Hinckley v. Schwarzchild and Sulzberger Co., ro7 App. Div. 470, 95 N.Y.S. 357 (Ig05); Salt Lake Automobile Co. v. Keith O'Brien Co., 45 Utah 2I8, I43 Pac. Ior5 (I9I4); General Investment Co. v. American Hide and Leather Co., 98 N.J. Eq. 326, I29 Atl. 244 (I925); Yoakum v. Providence Biltmore Hotel Co., 34 F. (2d) 533 (D.C. R.I. I929). There is some indication that business men regard this device as a convenient alternative to direct scaling-down. See Stempf, Revamping Capital Structures, r6 Nat'l. Ass'n. Accountant's Bull. 267, 277 (1934).

x9 Such an amendment does not in itself disturb the old accumulations, but if they are to be subordinated to future dividends on the new preferred, there is small likelihood that the accumulations will ever be paid. In order to fully protect dissenters they should be granted an injunction against the payment of any new dividends until the accumulations are reduced by an amount equal to their proper share of the new earnings if the new stock had not been issued.

${ }^{20} 270$ N.Y. 343 , I N.E. (2d) 457 (1936). See 46 Yale L.J. 985, 997 (1937) for a discussion of the complications arising from the attempt to prevent the subordination of the old preferred to the new securities.

${ }^{25}$ For examples, see American Malt Corporation v. Board of P.U. Commissioners, 86 N.J.L. 
corporation. Such a transfer involves the exchanging of new securities for the preferred stock and accumulations. In making the exchange, accumulations may not be given proper recognition. The exchange can be effected by three methods which will be illustrated by the use of the following example. Capital surplus and reserves of the $X$ corporation amount to $\$ 25,000$. There are accumulated dividends to the extent of \$Io on each share of preferred stock. The board of directors of the $\mathrm{X}$ corporation, having secured the necessary ratification by stockholders, agrees to merge with the $\mathrm{X}$ corporation which may be either a corporation formed for the purpose of effecting a scaling-down or a pre-existing corporation with a legitimate reason for merger. In return for each share and accumulations, the preferred shareholders of $\mathrm{Y}$ are offered one share of similar preferred stock in $\mathrm{Y}$ and one share of common stock. The common stockholders receive common stock in $\mathrm{Y}$ at a ratio of 8 shares for one share of $\mathrm{X}$ common. ${ }^{22}$

As a second possibility the two corporations may consolidate, forming a third corporation $Z$, the plan of share purchase being the same as above. ${ }^{23}$

A third device for accomplishing the same thing is for the $\mathrm{X}$ corporation to sell all its assets to the $Y$ corporation in return for the stock of $Y$, the stock being distributed to the shareholders of $X$ in the same manner. ${ }^{24}$

Here, as where recapitalization is effected by charter amendment, the non-

668, 92 Atl. 362 (Igr4); United Milk Products Corporation v. Lovell, 75 F. (2d) 923 (C.C.A. 6th I935). The plan which involves scaling-down of accumulations is discussed in Cravath, Reorganizations of Corporations, included in Stetson, Some Legal Phases of Corporate Financing, Reorganization, and Regulation $(x g \times 7)$. See In re Interborough-Consol. Corp., 277 Fed. 455 (D.C. N.Y. I92I); Petry v. Harwood Electric Co., 250 Pa. I42, I24 Atl. 302 (I924); Outwater v. Public Service Corp., I03 N.J.Eq. 46r, I43 Atl. 729 (I928), aff'd, ro4 N.J.Eq. 490, r46 Atl. 9r6 (r929); Purposes and Financial Plans of Industrial Reorganization, 7 Harv. Bus. Rev. Ig6 (I929); Baker and Malott, Introduction to Corporate Finance 274-94 (1936). The classic example of this device is the repeated recapitalization of what is now the United States Leather Corporation. The history of this company is set forth in Dewing, Corporate Promotions and Reorganizations (IgI4). See Colgate v. U.S. Leather Co. 73 N.J.Eq. 72, 67 Atl. 657 (I907), reversed, 75 N.J.Eq. 229, 72 Atl. 126 (r909); Windhurst v. Central Leather Co., IOI N.J.Eq. 543, I38 Atl. 772 (I927), aff'd, I05 N.J.Eq. 621, I49 Atl. 36 (1930), aff'd, Io7 N.J.Eq. 528, 153 Atl. 402 (1930); Prall v. U.S. Leather Co., 6 N.J.Misc. 967,143 Atl.382 (1928), aff'd, I05 N.J.L. 646, I46 Atl. 916 (Ig29). These materials are collected in Katz, Cases and Materials on Corporate Readjustment and Reorganization $67 \mathrm{ff}$.

22 While the ordinary merger plan is not so bold, this example illustrates the type of scalingdown practised in the U.S. Leather and other cases cited in note $2 I$ supra.

${ }^{23}$ While the distinction between merger and consolidation seems purely legalistic (and for our purposes the same problem is generally presented by both devices), the distinction gains significance in some situations. See 45 Yale L.J. 105, I07 (I935); 30 Mich. L. Rev. 1074 (1932).

34 Merger and consolidation are governed by statute and in many instances will be impossible. However, if the court is favorably inclined toward a particular consolidation, it will permit it to pass if couched in terms of sale of assets. In Paterson v. Shattuck Arizona Copper Co., I86 Minn. 6II, 244 N.W. 28I (r932), the court treated a consolidation as a sale of assets in order to avoid statutory difficulties. See 81 U. of Pa. L. Rev. 2I9 (r932); 20 Calif. L. Rev. 42 I (I932); 3 Univ. Chi. L. Rev. 330 (I936). 
litigated cases present the economically important problem. The non-litigious dissenter is faced with several unsatisfactory choices. He may sell his stock on the market; he may, in many states, avail himself of an "appraisal statute";25 or he may capitulate and accept the new securities offered him. In no case is he given the choice of retaining the interest in the future earnings of the enterprise to which his accumulated dividends supposedly entitle him.

Recapitalization may be either the sole purpose of a formal merger ${ }^{26}$ or it may be merely incidental to a genuine merger. In the former case, if litigation ensues, consistency with the amendment cases would require a court to enjoin the merger or the distribution of new securities without regard to the fairness of the exchange. However, where there is a genuine merger, there must be some distribution of new securities, and the court's only purpose is to see that the distribution is fair, i.e., that proper recognition is given to the accumulations. Courts, however, have not distinguished between these two situations and have generally enjoined either the merger or the distribution on the ground that the plan was unfair. ${ }^{27}$ MacFarlane v. North American Cement Corp..$^{28}$ is the only case found in which the court has, in the absence of laches, refused to enjoin a plan on the ground of fairness alone. There, however, the finding of fairness is probably attributable to the fact that the court attached excessive importance to the bargaining power ${ }^{29}$ of the common stock.

The dissenting stockholder has also been denied injunctive relief when his

${ }^{25}$ These statutes commonly provide that the dissenter is entitled to the "value" of his stock which in many cases is less than the par value of the shares plus accumulations. These statutes do not provide satisfactory remedies because the shareholder does not recover the investment value of his securities.

See Lattin, Remedies of Dissenting Shareholders under Appraisal Statutes, 45 Harv. L. Rev. (I93I); Levy, Rights of Dissenting Shareholders to Appraisal and Payment, I 5 Corn. L.Q. 420 (I930).

${ }^{26}$ See the history of the U.S. Leather Co., note I5 supra.

${ }_{27}$ Colgate v. U.S. Leather Co., 75 N.J. Eq. 229, 72 Atl. I26 (I909); American Malt Corp. v. Board of P.U. Commissioners, 86 N.J.L. 668, 92 Atl. 362 (rgr4); Lonsdale Securities Corp.v. International Mercantile Marine Corp., Ior N.J.Eq. 554, x39 Atl. 5० (I927); Geiger v. American Seeding Machine Co., I24 Ohio St. 222, 177 N.E. 594 (r931).

${ }^{28} \pm 6$ Del. Ch. 172, I 57 Atl. 396 (x928).

${ }^{29}$ The bargaining power of the common is only of significance when there is some necessity for the change, as in the case of an insolvent corporation. See p. 65t infra. Here the merger was with a more prosperous corporation, and therefore, as the court found, to the benefit of the shareholders of the North American Cement Corp. But there is no good reason why a requisite to such a merger should be an inequitable distribution of securities among the shareholders of the benefited corporation. Therefore the following statement of the court seems an amazingly frank recognition of the nuisance value of the common stock. "There could be no merger without the vote of common stockholders in its favor, and that vote could probably not be secured unless the merger plan was made attractive to them .... the conclusion must be that the merger plan indicates good business judgment in the interest of the company rather than such unfairness to any of its stockholders as amounts to fraud." MacFarlane v. N.A. Cement Corp. 16 Del. Ch. 172, I80, r57 Atl. 396, 399 (1928). 
action was untimely..$^{30}$ The two relevant cases suggest nothing more definite than that injunctive relief will be untimely if it is not sought before the proceedings under the plan are so advanced that an injunction would be destructive of the interests of the assenting majority. Petry ข. Harwood Electric Co.3x suggests another technique by which the dissenters may be protected. In that case the court, although denying injunctive relief, held that since merger effected dissolution, the preferred shareholder could specifically enforce his contract entitling him to a preference of par value plus accumulations upon dissolution. Two subsequent cases, however, have failed to adopt the reasoning of the Petry case. ${ }^{32}$

Whenever the dissenter's interests are small, it is possible that a court which would have denied injunctive relief because of laches or because the plan was "fair" may nevertheless invoke the doctrine of the Petry case and grant specific relief since such relief will cause less hardship to the new corporation. However, when the dissenter's interests are large, specific relief might require so much cash that it would harm the corporation more than injunctive relief, for injunctive relief merely keeps the corporation in status quo, while, when specific relief is given, the litigious preferred shareholders are entitled to full payment. Thus where the dissenter's interests are large, defenses should be as available in a suit for specific performance as they are when an injunction is sought.

\section{EQUITY RECEIVERSHIPS AND SECTION 77B}

Accumulated dividends have repeatedly been held not to constitute debts of the corporation. ${ }^{33}$ A corporation solvent in the equity sense probably cannot effect a reorganization through an equity receivership or under the Bankruptcy Act. Thus these devices cannot be initiated by common stockholders to improve their position at the expense of the preferred. ${ }^{34}$ When an insolvent corporation goes through a reorganization, the relative rights of preferred and common stockholders are matters of secondary interest. However, when a corporation, the capital structure of which includes cumulative preferred is reduced to insolvency, it is probable that there are dividend accumulations. The question must then arise as to what recognition is to be given these accumulations in the

${ }^{30}$ See Windhurst v. Central Leather Co., xor N.J.Eq. 543 (1927); United Milk Products Co. v. Lovell, 75 F. (2d) 923, 928 (1935).

${ }^{31} 250$ Pa. I42, 124 Atl. 302 (1924); see Simms, An Application of the Doctrine That Consolidation Effects Dissolution, I5 Va. L. Rev. 757 (I929).

${ }_{32}$ United Milk Products Corporation v. Lovell, 75 F. (2d) 923 (I935); Windhurst v. Central Leather Co., ro7 N.J.Eq. 528, 153 Atl. 302 (r924).

${ }^{33}$ Hamblock v. Clipper Lawn-mower Co., I48 Ill. App. 618 (rgog); Ellsworth v. Lyons, I81 Fed. 55 (C.C.A. 6th I910); Booth v. Union Fibre Co., I37 Minn. 7, I62 N.W. 677 (rg17); Kennedy v. Carolina Public Service Co., 262 Fed. 803 (D.C. Ga. r920); but see Roberts v. Roberts-Wicks Co., 184 N.Y. 257, 77 N.E. 13 (1906).

34 Accumulations are not a basis for the initiation of proceedings under $\$ 77 \mathrm{~B}$. In re Picadilly Realty Co., 78 F. (2d) 257 (C.C.A. 7 th 1935). 
distribution of new securities. If the matter were treated on the basis of absolute priorities, there would be nothing left for either class of shareholders, but as a practical matter in order to preserve the debtor corporation as a going concern, the necessary coöperation of the junior security holders is obtained by allocating some interest to them. ${ }^{35}$ In order to obtain the approval of the equity courts, the great majority of which take jurisdiction over reorganization plans, ${ }^{36}$ or to satisfy the requirements of the Bankruptcy Act, ${ }^{37}$ the allocation of securities must be in accordance with a "fair plan." ${ }_{38}^{8}$ Although there is no formula for a fair plan, this means, at least, that after the creditors have been satisfied, the interest left to the stockholders must be divided so that the preferred will receive somewhat more than the common. The exact ratio will be determined by the bargaining power of the representatives of the opposing interests. ${ }^{39}$ In these negotiations the existence of accumulations may have some effect.

Despite the apparent preponderance of cases protecting dividend accumulations against scaling-down, a great many corporations have succeeded in doing away with dividend arrearages. ${ }^{40}$ The difficulty of organizing an effective opposition, the lack of adequate information, and the expense of litigation-the familiar allies of management in intra-corporate disputes ${ }^{4-k e e p}$ many recapitalization plans out of the courts.

Thus we see that the security afforded by preferred stock is far less than appears on the face of the contract. The sophisticated investor knows this, but it seems that "widows and orphans" should be given greater protection or some warning of the real significance of the cumulative provision.

\section{II}

It is to be expected that disappointed common shareholders will seek to rearrange the capital structure of a corporation for the purpose of realizing at least a part of the anticipated returns. But some degree of speculation is implicit in the very nature of their investment. Preferred shareholders, on the other hand, accept at the outset the prospect of comparatively modest dividends in return for what they suppose is a greater measure of security. For this they

35 See Bonbright and Bergerman, Two Rival Theories of Priority Rights, 28 Col. L. Rev. ×27 (I928).

${ }^{36}$ See Katz, Protection of Minority Bondholders, 3 Univ. Chi. L. Rev. 517, 527 (r936);

4 Univ. Chi. L. Rev. 675.

37 Bankruptcy Act $\S 77$ B(b), 48 Stat. 912 (I934); II U.S.C.A. $\$ 207$ (b) (I936).

${ }^{38}$ See Spaeth and Friedberg, Early Developments under $\S 77^{B}$, 30 Ill. L. Rev. I37, I54 ff. (r935); Gerdes, A Fair Plan of Corporate Reorganization, x2 N.Y.U.I.Q. Rev. I (I934); 35 Col. L. Rev. 39r (r935).

${ }^{39}$ See Foster, Conflicting Ideals for Reorganization, 44 Yale L.J. 923 (I935).

$4^{\circ}$ See Dewing, The Financial Policy of Corporations 55, r248 ff. (3d ed. I934).

4 Berle and Means, The Modern Corporation and Private Property 80 ff. (I932); Weiner, Payment of Dissenting Stockholders, 27 Col. L. Rev. 547, 564 (Ig27). 
have expressly contracted. Thus any discussion as to the proper extent to which scaling-down should be permitted presupposes that there is some justification for the practice beyond the desire (and apparent ability) of the common shareholders to enrich themselves at the expense of the contractual rights of the preferred. Several rather unreal arguments have been advanced to this end.

It is said that a majority of shareholders have assented, and that the will of the majority should not be thwarted by the obstinance of a recalcitrant minority..$^{42}$ What better argument for the desirability of the change could there be than the approval of a large majority of the affected class? Several factors, however, seem to destroy the force of this argument. First of all, it frequently occurs that a large number of preferred shares are controlled by persons who are also interested in the common stock. Such persons are adequately compensated for any depreciation in the value of the preferred shares by a corresponding or greater appreciation of the common. Obviously, their approval is no evidence of the desirability of the plan from the standpoint of owners of preferred stock alone. Nevertheless, courts have minimized the significance to be attached to the articulation of common and preferred interests. ${ }^{43}$ Secondly, the management of the ordinary corporation holds more common than preferred stock ${ }^{44}$ and will mobilize sentiment in favor of the plan by the literature distributed in the solicitation of proxies, and paid for with corporate funds. On the other hand the considerable initiative and expense required for proxy solicitation generally prevents the marshaling of an effective opposition. 45

It has also been said that the presence of accumulations leads the common stock interests to influence the management to take unwise chances with a view of improving the financial position of the corporation by making large

${ }_{42}$ Stevens, Corporations 495 ( 9336 ); see note 22 supra.

${ }_{43}$ In MacFarlane v. North American Cement Corp., 16 Del. Ch. 172, 180, 157 Atl. 396, 399 (1928): ".... it is insisted by the complainants that the fact that almost one-half of the preferred stockholders .... voted in favor of the merger is of no evidentiary value in determining whether the proposed plan is fair . . . because they were actuated by a selfish motive,they had a large amount of common stock..... Conceding the vote.... to be of little evidentiary value .... it cannot be assumed that the motive actuating such vote was entirely selfish."

44 Berle and Means list the stockholdings by management in 1922 in twenty-six industries, including thousands of corporations. In seventeen of the twenty-six a greater percentage of common than preferred was held, and in all industries the par value of the common shares held by the management was substantially greater than that of the preferred. Berle and Means, The Modern Corporation and Private Property 51 (I932).

15 In this connection, the commentator in 46 Yale L. J. 985 , I003 (1937), doubting the feasibility of administrative control of the plan itself, recommends more stringent rules governing the information to be given in the solicitation of proxies. Undoubtedly such regulation would reduce the number of shareholders who would assent against their own interests, but it would not take care of the investor who is willing to sign anything. In most cases a careful reading of the literature now distributed will disclose the effect of the proposed plan. See for example, the Federal Water Corp. plan, note 4 supra. 
speculative profits. ${ }^{46}$ Scaling-down, on the other hand, will be conducive to a wise conservatism in the management of the corporate affairs. However, although this may be true once financial difficulties have arisen, the knowledge by management that the payment of accumulated arrearages may be avoided may lead it to indulge in unwise speculation even before financial difficulties have arisen. For the benefits of successful speculation go primarily to the common shareholders, whereas losses will result in an inability to meet preferred dividends. If these passed dividends need not be made up out of future earnings, the common stockholders are in effect gambling with the money of the preferred; they have more to gain than to lose by daring ventures. 47

Another argument urged is that the corporation as a whole will receive the benefits of the plan, ${ }^{8}$ or the argument is restated by saying that the capital structure will be put on a basis more e'conomically sound. ${ }^{49}$ In the main such an argument should appeal to the preferred shareholder only if he is going to profit from the plan. If the plan will result in an uncompensated scaling-down of the interests of the preferred shareholders, it is misleading to speak about the interest of the corporation as a whole, or the soundness of the capital structure. The argument would have some cogency if it could be pointed out that the rearrangement would result in increased profits. ${ }^{\circ}$ In this regard, it is sometimes said that the elimination of the obligation to the preferred shareholders will increase the credit of the corporation. It is difficult to see how this can be true since prospective creditors should realize that the existence of dividend accumulations in no way endangers them. It is possible, however, that after scaling-down, creditors will be less reluctant to lend because of the lessened likelihood of unwise dividend distributions to preferred stockholders by management aware that accumulations must be paid off before common stockholders can share in the earnings. A somewhat more persuasive argument is available where the corporation is in need of new capital.5x Again, as in the case of

${ }^{46}$ Foster, Conflicting Ideals for Reorganization, 44 Yale L. J. 923, 93 I (r935).

47 Ibid.

${ }^{8}$ MacFarlane v. North American Cement Corp., I6 Del. Ch. I72, I57 Atl. 396 (Ig28), noted in 45 Harv. L. Rev. 930 (I932); $c f$. Colby v. Equitable Trust Co., r24 App. Div. 262, ro8 N.Y.S. 978 (Igo8).

${ }_{49}$ The letter of Sept. 26, 1936, to the stockholders of the Goodyear Tire and Rubber Co. urged the acceptance of a "fair and financially sound plan which would .... recognize the rights of the respective classes of stock and strengthen the capital structure of the Company."

${ }^{50}$ Although increased profits would not increase the amount of dividends payable to the preferred, the result might be the availability of earned surplus which would never have existed had the improvement not taken place, and therefore an increase in the amount actually paid to the preferred.

5I This is ordinarily true only where the corporation is in real financial embarrassment, and in such cases some scaling-down is to be expected. See p. 651 supra. If the new capital is needed for expansion, the investment should be sufficiently attractive to secure new capital without scaling-down. 
ordinary creditors, the existence of arrearages has no effect on new securities which rank ahead of the old preferred stock. Nevertheless, the psychological effect of eliminating accumulations will probably make new prior securities more salable. Recapitalization, also, may simplify current financing by permitting distribution of current earnings to more than one class of security holders. Since this will enable the corporation to issue more of the old types of securities the corporation may be able to obtain new capital without complicating the capital structure by issuance of new types of securities..$^{52}$

However, insofar as the scaling-down gives a false color to the financial history and prospects of the corporation, it should not be encouraged. But frequently, a corporation while not insolvent may be in such a condition that it cannot hope to raise new capital from outside sources, but must look to the existing shareholders from whom, in any case, new funds can be raised with a minimum of promotional expense. It is argued that the common stockholders will not participate unless they are offered some inducement, such as the elimination of accumulations. ${ }^{53}$ And since preferred shareholders may be unwilling to make a speculative investment, and, also, since the amount of preferred stock outstanding is ordinarily comparatively small, the only possibility of raising the needed capital may be to induce the common shareholders to participate. This argument seems to have persuasive force only in those rare situations where there is a concurrence of the following factors: a real prospect that new capital will increase earnings to such an extent that preferred stockholders will be compensated for the relinquishment of their accumulations, and the unavailability of new capital at better terms from any source other than common shareholders.

It is also possible that scaling-down may be justifiable when it is necessary in order to retain active managers whose services are necessary to the continued prosperity of the business. It is conceivable that sizable blocks of common stock are held by the men whose executive ability and ability to get contracts through goodwill are essential to the successful operation of the enterprise. Suppose that the common shareholders have not been sharing in the profits because of the existence of dividend arrearages on the preferred. The active managers become impatient and threaten to take their talents elsewhere unless the accumulations are scaled down. In a case where the ability of these men is absolutely essential to the future success of the business and for some reason the matter cannot be handled by salary and/or bonus adjustments, it may be advisable for the preferred to capitulate. But such rare cases should stand on their own facts and do not argue for scaling down as a general policy.

${ }^{2}$ The desirability of raising capital by the sale of stocks rather than securities carrying fixed capital charges is pointed out in Dewing, Financial Policy of Corporations 946-47 (3d. ed. 1934).

53 This argument is advanced with reference to stockholders generally as against creditors in Swaine, Reorganization through Judicial Proceedings, included in Some Legal Phases of Corporate Financing, 8 Lectures on Legal Topics r33, $_{54}$ (r93 $\mathrm{r}$ ). 
III

We have seen that the traditional handicaps of minority security holders operate to keep many plans out of court. The only machinery thus far developed to insure court approval of reorganization plans which does not require dissenters to take the initiative is the administration of insolvent corporations by the bankruptcy and equity courts. The prevalence of scaling down apart from bankruptcy despite numerous adverse decisions and despite the absence of any persuasive justification suggests the adoption of legislation vesting in the state courts of equity a similar supervisory power over "voluntary" plans of recapitalization by amendment and merger. ${ }^{54}$ Such legislation would require that recapitalization plans be approved by the court before being submitted to the stockholders. The advantage of this system is that the court, without throwing the burden of instituting litigation upon dissenters, would have the opportunity to scrutinize the plan and to withhold approval if preferred shareholders were dealt with unfairly. The added burden placed upon the courts by such legislation ${ }^{55}$ would be justified only if courts would seize the opportunity to strike down unfair plans even in the absence of strong opposition. Although under ${ }_{77} \mathrm{~B}$ plans have not been rejected unless strongly opposed, ${ }^{56}$ several factors indicate that courts may adopt a stricter attitude in regard to scaling down by solvent corporations. Scaling-down plans are relatively simple and do not involve the interests of many classes of security holders. Furthermore, the courts in the past have been antagonistic to scaling-down. Most important of all, there is not the necessity, as in the case of insolvent corporations, that some plan be adopted. The withholding of court approval would obviously not prevent the voluntary exchange of old securities for new so long as the interests of dissenters were preserved, but such withholding would warn prospective assenters of existing unfairness and would act as a prophylaxis against and a corrective of unfair plans. In the interests of a less complex corporate structure, it would probably be desirable for the statute to compel dissenters to join in a fair plan. But the retroactive application of such a statute to prior issued securities would probably raise constitutional difficulties. .7

Of course such a statute would not indicate what is a fair plan. There has been much speculation as to the nature of a fair plan under $\S 77^{B},,^{8}$ but the less

54 For similar Canadian legislation see $\$$ II 2 of the dominion Corporation Act; Fraser Reorganization of Companies in Canada, 27 Col. L. Rev. 932, 95I ff. (I927). Such supervisory power has been recommended for other purposes. See 44 Yale L. J. 1025, 1049 (I935); 36 Col.

L. Rev. 674,675 (1936).

${ }_{55}$ See 46 Yale L. J. 985,1003 (1937).

${ }^{56}$ See Foster, Conflicting Ideals for Corporate Reorganization, 44 Yale I. J. 923, 929 (I935); Bonbright and Bergerman, Two Rival Theories of Priority Rights, 28 Col. L. Rev. I27, I45 (I928).

57 See Geiger v. American Seeding Machine Co., I24 Ohio 222, 239, I77 N.E. 594, 600 (I93).

$s^{8}$ See note $3^{8}$ supra. 
pressing need for recapitalization renders the same considerations inapplicable here. It should be held that scaling-down of accumulations is justifiable only where it results in the benefits to the preferred shareholders discussed above. Too much consideration should not be given to the improbability that accruals will ever be paid, ${ }^{59}$ or broad and unsubstantiated statements concerning benefits to the corporation as a whole.

It has also been suggested that recapitalization could be more effectively supervised by an administrative board.60 Commissioner Douglas of the Securities and Exchange Commission recently announced that the Commission will ask for power to regulate, among other things, reorganization proceedings. ${ }^{6 \mathrm{I}} \mathrm{It}$ might be a desirable substitute for state action to authorize the Securities Exchange Commission to supervise recapitalization to the extent that such supervision would be constitutional. In the absence of legislation providing for supervision by court or administrative board, the protection of accumulations, like other problems of minority security holders, must await either the creation of an association like the British Shareholders Protective Association, ${ }^{62}$ or a changed business morality.

Commentators have pointed out the undesirability of non-cumulative preferred stock.$^{63}$ That this feeling is shared by the investing public is evidenced by the fact that such securities are not highly regarded on the market. ${ }^{64} \mathrm{We}$ have seen that in many instances the cumulative provision is not only of no practical value, but is misleading. Therefore, unless the accumulations are fully protected, the desirability of any type of preferred stock as an investment is doubtful.

\section{INDUSTRIAL STRIKEBREAKING-THE BYRNES ACT}

Articulate opinion of industrial strikebreaking has been almost unanimously hostile.x There is now little question of the desirability of government interference if a law can be drawn which is both constitutional and effective. In its broadest sense strikebreaking has taken three principal forms: (I) Replacements. The most nearly justifiable form. Employers insist that they are merely

s9 See Windhurst v. Central Leather Co., ror N.J. Eq. 543, r38 Atl. 772 (I927).

${ }^{60}$ See 46 Yale L. J. 985, 1003 (1937).

6x Chicago Tribune, April 18, x937, pt. 2, p. 7, col. 6.

${ }^{62}$ See Douglas, Directors Who Do Not Direct, 47 Harv. L. Rev. 1305, 1330 (1934).

${ }^{6} 3$ See Lattin, Is Non-Cumulative Preferred Stock in Fact Preferred, 25 Ill. L. Rev. 148, I64 (1930); 74 U. of Pa. L. Rev. 605, 608 (r926). But see Berle, Non-Cumulative Preferred Stock, 23 Col. L. Rev. $35^{8}$ (r923).

${ }_{64}$ Professor Berle has called non-cumulative stock the "waif of the stock exchanges." Berle, op. cit. supra note $6_{3}$, at 358 .

× See, generally, 85 U. of Pa. L. Rev. 406 (I937); Levinson, I Break Strikes (I935), II Fortune $5^{6}$ (Jan. 1935), 9o New Republic 227 (Mar. 3I, 1937). But see Pinkerton, Strikers, Communists, Tramps, and Detectives ( 1878 ). 